\title{
Orpheus in Pieces
}

\author{
PHILIP ARMSTRONG
}

\begin{abstract}
On 7 February 1863, the Royal Navy corvette H.M.S. Orpheus, en route from Sydney to Auckland, was wrecked at the entrance of the Manukau Harbour, with the loss of 189 men. This essay offers a "new materialist" retelling of that story, one that seeks to identify the roles played by nonhuman agents of various kinds (such as sand, mud, trees, animals, tides, rain, wind) alongside the roles played by human protagonists (both individual and collective). To help convey the sense of this event as a production by an ensemble cast of actors, I have used the form of creative narrative nonfiction, while remaining within the documented facts.
\end{abstract}

\section{Rollers}

Under the long light of an Auckland summer evening, the rollers come in from the Tasman. Gently, they wash several bodies towards the shore. Some have been stripped naked by the rough seas two days earlier; others are still wearing their duck trousers and shirts. The waves arrange them like driftwood along the black sand.

Meanwhile, on the other side of the Auckland isthmus, three gentlemen board H.M.S. Miranda, a Royal Navy vessel at anchor in the Waitemata Harbour. The New Zealand premier, Alfred Domett, and two other government men are here to conduct initial inquiries into the wreck of H.M.S. Orpheus, which, arriving from Sydney, ran aground and broke up at the entrance of the Manukau two nights ago, on 7 February 1863, with the loss of 189 men, including Commodore William Farquharson Burnett CB. How could a newly built corvette, with its commodore, commander, and sailing master on the bridge, proceeding under steam and sail on a fine summer's day, have come to grief so catastrophically only a couple of cable lengths from land?

Aboard Miranda, Premier Domett and his colleagues put their questions to surviving Orpheus crew and officers. Answers are given reluctantly, with disagreements and contradictions, until the proceedings are closed down by Miranda's first lieutenant on the grounds that Royal Navy regulations prohibit an investigation aboard a man-of-war in the absence of the commanding officer. $^{1}$

A coroner's inquest in Wellington, held a fortnight later, doesn't get much further. At one point, Mr. F. D. Fenton, the assistant law officer observing on behalf of the colonial government, objects to questions "being put to common seamen that involve reflection on the judgement of their superiors."

Two months after the wreck, the British Admiralty convenes a court martial in Portsmouth aboard the Victory, Nelson's old ship. A jury of six captains puts questions to selected survivors, and concludes " $[\mathrm{t}]$ hat Her Majesty's Ship Orpheus was lost from being run on shore at the entrance of the Manukau River, the Bar having shifted," and "[t]hat no blame whatever is attributable to Commodore Burnett C.B. or the Officers and Crew of the Orpheus." 3 This verdict will be set in stone back in New Zealand, when the promontory that overlooks the breakers where the ship and men were lost is renamed "Burnett Head."4 


\section{Cotton}

February 4, 1863: Commodore Burnett is in a hurry.

The Orpheus is halfway across the Tasman Sea, on course for Auckland. Under full sail, closehauled into a steady easterly, the ship has made good progress for the first few days out of Sydney. The Tasman is "in one of its rare good moods," yet the Orpheus is a "wet ship"-not leaky, but with a long low hull designed to cut through the waves rather than going over themso an occasional high comber crashes over the deck. ${ }^{5}$ Commodore Burnett's frock coat is soaked, but his arms are protected from rubbing against the wet wool by the cotton lining of the sleeves. ${ }^{6}$

The cotton for that lining was most likely picked in the American South by slaves, whose labour provides the biggest source of raw material for the vast British cotton industry. Over the last couple of years, however, since the start of the American Civil War, cotton from the South has had to penetrate the Union Navy's cordon, which is stationed around the Atlantic and Caribbean seaboard of the Confederate States in an attempt to choke off their access to overseas markets. The blockade runners used to escape the cordon are fast-moving vessels, supplied to the Confederacy in some cases by British shipwrights, in contravention of Britain's officially neutral position. Once through the cordon, the runners make for Nassau, where the cotton is transferred to ships bound for England, and so eventually to the steam-driven mills of Manchester to be woven into, among a great many other things, cotton lining for naval uniforms. $^{7}$

So it happens that cotton is one of the main reasons Commodore Burnett finds himself in such haste. Tensions are high between Britain and the US, because the Confederacy has been using "cotton diplomacy" - that is, manipulation of the British demand for cotton - to try and gain support, covert or outright, against the Union. US resentment of this connection has at times come close to overflowing. For instance, a little more than a year ago, in November 1861, Captain Charles Wilkes of the U.S.S. San Jacinto almost provoked Britain's formal entry into the war when he intercepted the Royal Mail vessel Trent off the coast of Cuba and took prisoner two Confederate envoys, on their way to London to try and negotiate stronger diplomatic, financial, and military support for their side in the conflict. Wilkes' action caused some belligerent celebration in the US press and some equally belligerent outrage in Britain. For a short while, war between two countries seemed imminent: Lord Palmerston, the British prime minister, instructed the governor general of Canada to prepare for mobilisation against its southern neighbour, and strategic plans were drawn up by the War Office in London. ${ }^{8}$ In December 1861, the Orpheus, on her first commission following her launch a year earlier, accompanied a troopship to Halifax, Nova Scotia, in order to strengthen British forces there. ${ }^{9}$ But before the year was out, a diplomatic solution was reached, and the two Confederate commissioners sailed for England on 1 January $1862 .{ }^{10}$ During the following six months, the Orpheus made its way from Canada, via the Caribbean and South Africa, to Sydney. ${ }^{11}$

Still, as Commodore Burnett knows better than most, antagonism between Britain and the Union remains active. Occasional outbreaks of minor hostilities, including exchanges of fire, are still taking place in the Caribbean between Royal Navy vessels and the Union blockading squadron. ${ }^{12}$

Along with the possibility of war at his heels, Burnett is equally conscious of the likelihood of war ahead, which is the second factor behind his desire for a swift voyage. In recent months, 
New Zealand's Governor George Grey has been lobbying for additional naval support, citing public fears that Waikato Māori are preparing to attack Auckland: "the fact of some of the natives discussing wholesale plans of murder," he wrote in December 1862, "shows that we stand on a very insecure foundation." ${ }^{13}$ (What his letter didn't mention was his own preparations for invasion, which included deployment of British troops to extend the Great South Road from Auckland into Waikato territory. ${ }^{14}$ ) Grey's alarm call was accompanied by a supporting letter from Premier Domett, which restated the matter more urgently still:

as powerful a Naval force as the general requirements of the Station will permit, should have its headquarters in New Zealand. ... [T] [he means of conveying a military force of some kind to any parts of the coast should always be on hand - and ... the Governor himself should have the power of visiting the various parts of the Island with greatest celerity, and accompanied by such a show of force as may command respect.... [T] he moral effect on the Natives that they may thus be unexpectedly visited at any time by vessels of war, is of the greatest advantage. ${ }^{15}$

It is to assess these requests that Commodore Burnett is now taking the Orpheus to Auckland. But he knows he has to keep the visit as brief as possible. He is under Admiralty instructions to keep his forces concentrated at Sydney, in case of any flare-up of tensions between the Royal and US navies that might spill into the Pacific. ${ }^{16}$

Burnett's tight schedule requires the Orpheus to arrive in Auckland on February 7. To reach the Waitemata Harbour the ship needs to sail northeast around Cape Maria van Diemen, at the top of New Zealand's North Island, and then south down the east coast of the Northland Peninsula. But last night, February 3, the wind changed to the southwest, which threatens to hinder progress on that last southern leg of the voyage, making it impossible to reach the Waitemata in time. So it is that, after consultation with the ship's commander, first lieutenant, and sailing master, Commodore Burnett decides to make for the Manukau Harbour on Auckland's west coast instead. ${ }^{17}$

\section{Names (1)}

In the only extant photographic image of the Orpheus, the ship looks skeletally thin, as if shown in x-ray: all bare rig and naked masts and spars. ${ }^{18}$ But in life, under full sail and with its sixteenfoot-diameter steam-driven screw churning, Orpheus would have given a different impression. A new model Royal Navy corvette, a Commodore's vessel, the flagship of the Australian squadron, 230 feet long and armed with twenty nine-foot guns and one of ten-foot-four ${ }^{19}$ : "the largest and best-equipped man of war that had ever come into the South Seas." ${ }^{20}$ All in all, a formidable declaration of British maritime power.

The ship's name made that declaration plain. As any Victorian schoolchild would know, Orpheus was the ancient Greek hero who could make everyone dance to his tune-everyone and everything. So potent and moving were his lyre playing and singing that trees pulled out their roots and clumped in his direction, gathering round and bending down to listen. Rocks rolled forward to join them; the breeze stopped blowing; even the waters altered their flow.

H.M.S. Orpheus, too, commanded the obedience of the elements. The woods were gathered round, to be sure: building a ship of that size required the timber of nine hundred trees. ${ }^{21}$ But by the mid nineteenth century, Britain's timbers were severely depleted, thanks to the shipbuilding frenzy of the Napoleonic wars. As John Keats wrote in 1818, imagining Robin Hood returned from the grave to mourn the loss of the medieval greenwood: "[h]e would swear, 
for all his oaks, / Fall'n beneath the dockyard strokes, / Are rotted on the briny seas."22 Orpheus, therefore, must have been made from foreign timber: either teak from Ceylon, or Quercus robur, the so-called "English Oak," but imported from Italy.

When it came to commanding the other crucial maritime elements, wind and water, the combination of a full square rig and two coal-fired four-hundred-horsepower engines made H.M.S. Orpheus a potent embodiment of modern industrial power over the environment. Yet the fate of its classical namesake might have provided as much warning as promise. Such was the original Orpheus's belief in his own capabilities that, when his beloved wife Eurydice died, he went to the underworld to retrieve her soul. Amazingly, his song evoked pity even in Hades and Persephone, the king and queen of the dead, moving them to permit Eurydice to follow her husband back to the living world — on condition that he walked ahead, and did not look back even for a moment before leaving the underworld. Was it overconfidence or anxiety that made Orpheus turn to glance over his shoulder just before stepping into the light, so that his beloved slipped back forever into the depths?

His subsequent grief would cause his own death, too. Refusing to love another woman, he spurned the advances of the Maenads, who in fury tore him to pieces and scattered his limbs in a river. His disembodied head, trailing blood, continued to sing gorgeously but dolefully as it floated out to sea. ${ }^{23}$

\section{Names (2)}

Opinions differ about how the Manukau got its name. The most prosaic explanation relates it to the forests of Mānuka (Leptospermum scoparium) that once covered the shores. ${ }^{24}$ But there are other etymologies, which focus more on the notorious harbour entrance.

Local Māori tell two stories describing how their tūpuna arrived at the name. In the first, the crew of Tainui, one of the legendary waka on which Polynesians first emigrated to New Zealand, struggling through the breakers over the bar, named the harbour for their navigator's worried look: "Te Mānukanuka o Hoturoa" (which can be roughly translated Hoturoa's nervousness). ${ }^{25}$ In the second story, the anxiety belongs to the crew: aghast at the thought of entering such a place, they told their navigator the air was full of warning cries. "He manu kau noa iho," said Hoturoa: "it is only birds"-recognising the whickering voices of ngā takapu, gannets, soaring to and from their clifftop colonies. ${ }^{26}$

There's a fourth possible etymology too. Maybe the word Manukau echoes the name of Taramainuku, the supernatural waka captain in the sky, who each night casts his net made of stars (which the Pākehā call the Milky Way) to gather up the souls of the drowned. ${ }^{27}$ Māori mariners who came to know the Manukau Bar over hundreds of years would repeat a warning formula: "Kei te tua o Manuka, te kite ki muri ki te Kupenga-o-Taramainuku." If you want to escape the net of the soul-catcher, don't look behind till you're through! ${ }^{28}$

The unhomely terror that attached to the harbour entrance - evoked, at least according to these stories, every time its name was mentioned-was recognised by Europeans in their turn. In the words of Edward Wing, the signalman on duty on the day of the wreck, the Manukau's entrance was "believed by mariners to be among the worst in the world." 29 It's easy to understand why. The harbour has a surface area of 340 square kilometres, but the only passage to the Tasman is less than two kilometres wide. Twice a day, a great quantity of the water held in that huge vat flushes in and out of the tiny bottleneck. In addition, the ebb tide contends with, and the flood 
tide is swollen by, the full impetus of the fractious Tasman Sea. As a result, the entrance is criss-crossed, just beneath low-tide level, with a treacherous system of bars and banks. Composed of the heavy black ironsand for which Auckland's West Coast beaches are well known, these hidden ramparts are constantly building, shifting, and rebuilding just beneath the rollers and breakers they cause. ${ }^{30}$

\section{The Chart ${ }^{31}$}

The only man aboard Orpheus who knows the Manukau - the only one who has passed the bar previously-is Frederick Butler. (As it turns out, he will also be one of the wreck's survivors.) The first time he visited the Manukau, he was Quartermaster of H.M.S. Harrier. After that he decided he'd had enough of life at sea and tried to desert in Sydney. But the Service caught up with him, and that's why on this voyage he's a prisoner aboard the Orpheus, being transported back to Auckland to face court martial.

Right now, looking through the bow ports, he can see the Orpheus is among breakers-which means they're heading for the sandbanks. He tells Lieutenant Mudge that they're going wrong. Mudge takes no notice, but Butler's crewmates have heard, and at their urging, Butler proceeds to the bridge, to tell the sailing master. Sailing Master Strong tells him they are following the chart he holds. Butler tells him the chart is wrong: it was drawn ten years ago from a survey taken by Captain Drury, in H.M.S. Pandora.

At this moment, the ship touches ground astern. It's just a slight jolt, but everyone feels it: the momentary slowing, the slipping-grinding of oak on ironsand. But then Orpheus continues as before, for ten seconds, twenty, thirty.

Butler continues, as urgently as he can, to try and persuade the senior officers that they need to abandon their chart. Eventually, Commodore Burnett asks him where he thinks the channel is, and Butler points northwards, to a patch of calm water. The Commodore orders the helm put to starboard - at last, and just too late.

About ninety seconds later the ship strikes hard: the keel slides smoothly onto the submerged Middle Bank. The Orpheus goes from full speed to a complete stop, and everyone is thrown to the deck.

\section{Signals $^{32}$}

From the signal station atop Paratutae Rock, a tall rocky outcrop that stands out from the northern headland, Edward Wing looks on with dismay.

On seeing the ship approaching, nearly an hour ago now, he had turned his spyglass to the channel and seen the tide was near full and the bar navigable. Hurrying to the signal mast, he hauled two squares to the yardarm: "take the bar." That was ten minutes work. But the spyglass in his sweaty hands showed him the ship still heading south, under full sail and steam, on a course that would miss the entrance to the channel. So he lifted the mast's north arm: "keep more to port." That took ten more minutes and by the time the ship turned to come in, it was in the wrong position, just where the breakers were. Chest straining, Wing raised another signal, "danger: keep back," but ten minutes more was precisely the right amount of time required, at that speed, to bring the Orpheus onto the Middle Bank. 


\section{The Boats ${ }^{33}$}

As soon as the Orpheus grinds to a halt, Commodore Burnett orders the sails clewed up and the engines full power astern, but the screw has jammed in irons and. Instead of moving off the bank, the ship slews around, side on to the outflowing tide, and careens over to port. Waves smash across the exposed deck, sweeping away equipment and men.

With great difficulty, two of the ship's boats, a cutter and a pinnace, are lowered. Despite the chaotic seas, these make it to safety with a dozen or so survivors in each. But the forty-foot launch, which might have taken many more, isn't so fortunate. As it's being readied for departure, the ship's anchor catches in the gunwale and a great wave lifts the Orpheus so it drags the launch on end, capsizing it and hurling those aboard into the breakers.

\section{Voices}

Of the other vessels in the harbour that day, the only one big enough to attempt a rescue is the steamer Wonga Wonga, under the direction of the harbour pilot, Captain Thomas Wing, Edward Wing's father. Unfortunately, the steamer is currently located in the south channel. Wing, in his much smaller pilot boat, can take his four Māori crew-Nehana, Timiona, Roma and Kuki-and row directly across the shallow middle of the harbour to the north channel where they will help pick up survivors, but the Wonga Wonga has to steam out beyond the heads of the harbour and back down the northern side before it can reach the Orpheus. ${ }^{34}$

By that time the ship has been exposed to breaking seas for several hours. Her masts are angled at thirty degrees from the horizontal. The three-ton cannons have broken loose and smashed their way across the deck, crushing timbers and men alike as they go. Those still aboard are clinging to the shrouds while the waves chop at the masts below. It's too dangerous for the ship's pinnace and cutter, Wing's pilot boat, or the Wonga Wonga to get close. The rescuers can only try to drag to safety those who have jumped or been washed overboard. ${ }^{35}$

At 8.30pm, the Orpheus's mainmast falls, taking to their deaths the commodore, Commander Burton, Lieutenant Mudge, Sailing Master Strong and about fifty crew. Relieved of the weight, and pushed by the increasing force of the now incoming tide, the ship rears up, stands for a moment on its keel-turning at the gates of the underworld - and crashes down to starboard. With the force of that collapse, the mizzenmast and the remaining men are thrown to destruction. ${ }^{36}$

Did the Orpheus sing in death, like her namesake? James Mason, the assistant boatswain, who survived after being flung into the sea when the mizzenmast fell, will recall (many years later) that in the final hours the men could be heard "singing in the face of death," and calling encouragement to each other. ${ }^{37}$ Another survivor of the collapsing masts, midshipman Hunt, would write to the Times in 1880 , emphatically reinforcing the frequently repeated claim that the last of Orpheus crew in the rigging had met their deaths with "three parting cheers." 38 Thomas Wing, however, flatly contradicted these claims, asserting that those on board the rescue vessels as they wallowed helplessly near the disintegrating ship heard only "the screams of men being launched into eternity." 39

\section{Materials}

Despite two hearings and a court martial within as many months, and many re-litigations by survivors, rescuers, and maritime historians since, the wreck of the Orpheus continues to evade simple explanation. 
Were the commodore and his sailing master dogmatically reliant on Drury's 1853 chart? Did the double pressures of war behind and war ahead - the smouldering tensions between Britain and the Union, and the demands for naval support from New Zealand's colonial governmentforce Burnett into hasty decisions? Or did Edward Wing, through youth and inexperience, signal incorrectly or belatedly, giving those aboard the Orpheus false reassurance about the safety of their course?

Perhaps a more rounded explanation emerges when we remember that humans are not the only agents at work in the world. Maybe the fate of Orpheus tells us something important about our tendency to fantasise that the world of non-human matter, organic and inorganic, cannot help but dance to our tune. ${ }^{40}$

Materials of many kinds were preparing to take leading roles in this disaster well before 7 February. The haste that propelled Orpheus into the Manukau, instead of taking the longer voyage to the much safer Waitemata, was fuelled by cotton, that filmy, fluffy stuff which in 1863 was playing such a catastrophic role in the American Civil War, simultaneously driving families to starvation in the north of England and escalating the tensions between the Federal and Royal navies to the point that Commodore Burnett, with the Admiralty breathing down his neck, felt obliged to take his lethal shortcut.

Meanwhile, on shore, other nonhuman agents were already in on the act. Edward Wing testified vociferously that he hoisted the right signals from the signal station at the right times. But he also complained he couldn't communicate more precisely because he didn't have any Marryat signals. These would have enabled him to use just three flags to represent a triple-digit number, directing the Orpheus's signal officer to an unequivocal message in his codebook. 809: You will be on the bank if you do not change your course. ${ }^{41}$ Unfortunately, as the Wings father and son attested repeatedly, no replacement Marryat flags had been supplied to the Paratutae signal station after the original set had been destroyed. They had, according to Edward Wing, been eaten by rats - descendants of the animals who were the first permanent European settlers in Aotearoa, self-introduced, as in so many other colonial locations, from the earliest visiting ships. ${ }^{42}$

The role played by other kinds of nonhuman agents in sinking the Orpheus was actually recognised in the Admiralty's verdict on the disaster. As quoted earlier, the court martial concluded that "no blame whatever" was attributable to the crew or officers of the Orpheus, "the Bar having shifted." 43 But in ascribing culpability to millions upon millions of shifting particles of sand and brine, the presiding captains in Portsmouth were simplifying things.

The sand of the Manukau Bar and Middle Bank is no ordinary sand: it a lively aggregate of silica and calcium carbonate combined with the pumice and black magnetite hurled outwards by the area's many volcanos over centuries and millennia. Which means, for one thing, that the observations of Orpheus's sailing master would have contradicted Edward Wing's signals. Like all European seamen, Master Strong would have been trained to navigate shallow channels by looking for "blue water" - an area unbroken by surf, which showed blue because of the pale sand beneath. Above a black sand seabed, however, water does not show blue. ${ }^{44}$

Moreover, that particular patch of seabed itself had reason, in 1863, to behave rather more shiftily than it ever had before. For more than ten years, European settlers had been cutting 
swathes of forest surrounding the Manukau harbour to free land for pasture, and to extract wood for fuel and construction. The resulting runoff, quickened by the teeming Auckland rains, poured an unprecedented volume of sediment into the tide to enlarge the Middle Bank and provoke it into movement. ${ }^{45}$ Over the course of that busy decade, then, the saws and axes of the new settlers nourished and awakened a leviathan which, moving its great flukes, swam northwards with unprecedented speed from the position marked on Drury's 1853 chart.

\section{Te Pu-Rākau}

Local Māori, meanwhile, came to their own conclusions about the disaster-or perhaps the same conclusions, seen from a different angle. Until the eve of the wreck there had stood on Puketutu Island, in the north-east corner of the harbour, a püriri (Vitex lucens) tree of great antiquity, whose mana was sufficient to earn it a name: Te Pu-Rākau. Mourners had for centuries worn its glossy palmate leaves at their tangi; would-be parents had prayed in its shadow that their unions would bear children; navigators of waka used it as a navigation point. And a hundred generations of kererū feasted on its berries, spreading the tree's offspring all around the harbour shores. Bringing harm to a tree possessed of such mana would inevitably bring disaster. ${ }^{46}$

To European settlers, though, pūriri was "New Zealand Oak," prized solely for the hardness of its timber. So at last in 1863, on 6 February (of all dates), having used up all the nearby trees, a European farmer chopped down Te Pu-Rākau for fence posts. Next day, Orpheus made its landfall in unknown sands. ${ }^{47}$

\section{Deliveries}

Hour after hour, in the fading light, the rescue boats ply the waters of the harbour entrance, dragging the dead and the nearly dead crew from the gates of Rarohenga. Other rescuers search the beaches themselves. No survivors have made it to shore by themselves, but the searchers come across pieces of flotsam: a chest of tea, a cask of peas, a case of candles, and the Commodore's cot, still neatly made up. ${ }^{48}$

The cot's missing occupant comes to rest two days later on Piha beach, six kilometres north. Local Māori wreathe their brows with pūriri leaves and give him a chief's burial. When Royal Navy officers arrive to bring the body back to Auckland for re-interment with full military honours, the villagers exhume Burnett and carry him south on behalf of colonial invaders who don't know their way through the bush. ${ }^{49}$

For a long time, the Tasman keeps up its deliveries. Three bodies on 27 February, and four more during March at Waitara, two hundred kilometres south of the Manukau. Five at Kaukapakapa, tucked around the corner of the Kaipara Harbour, fifty kilometres north. Easter tides bring four more bodies ashore at Muriwai beach, just ten kilometres from the site of the wreck. More come in the months and years that follow, the last being no more than a skull and some bones uncovered from the sand at Burnett Head in $1879 .{ }^{50}$ Of the Orpheus itself, nothing returns but a few spars pulped by the waves, and a couple of rusted cannonballs rolled on the beach by the surf at Puketutu Island, like two full stops or two-thirds of an ellipsis. ${ }^{51}$

The great majority of those drowned never make it back to shore. Most were lubbers, new recruits, with no knowledge of the sea or ships: butchers, bakers, joiners, shoemakers, tailors, framers, tilers, farmers. Orpheus was crewed by men who knew many different worlds of things, but precious little about the new wooden world they now inhabited. Many were 
teenagers and some even younger. Not one in fifty could swim-not that swimming would have helped much amongst the chaotic breakers over the Middle Bank. ${ }^{52}$

One hundred and twenty-six of these men and boys have remained on the seabed, and over decades their flesh has washed away and their bones have been ground into sand by the sands around them. But perhaps, someday soon, they will re-enter the action. In 2017, an Australian mining concern, Trans-Tasman Resources, secured the approval of the New Zealand Environmental Protection Agency to dredge a billion tonnes of sand from the seabed off the North Island's west coast and mine it for iron. And so it seems possible that, some time in the next few years, the so-called mortal remains of 126 Orpheus crew will be sucked into "seabed robot crawlers" and whisked above to "integrated mining vessels." 53

But even if it does come to pass that the Orpheus's unclaimed dead are brought back from the underworld, no sooner will they see the light of day than, like Eurydice, they will be consigned once more to the depths. On board the ships, the seabed sediment will be run through magnetic separators to extract the iron, and the unwanted remains expelled back into the deep. For the particulate souls of Orpheus's crew, as no doubt for all of us, there might be an afterlife, but there will be no resting in peace.

\section{Acknowledgements}

I am grateful to the editor of JNZS, Anna Green, and to the two anonymous reviewers who provided invaluable corrections to an early draft of this essay. Any errors that remain are my own.

\footnotetext{
1 "Minutes of Evidence Taken on Board her Majesty's Ship Miranda, in Auckland Harbour, on the Night of Monday, February the 9th, 1863, before the Hon. A. Domett, Colonial Secretary; Hon. Dillon Bell, Native Minister; and Hon. Thomas Russell, Member of His Excellency's Executive," enclosure no. 2 in "Further Papers Relevant to the Loss of Her Majesty's Ship 'Orpheus,"” Appendix to the Journals of the House of Representatives, 1864 Session I, D-04, National Library of New Zealand, http://www.atojs.natlib.govt.nz/cgi-bin/atojs?a=d\&cl=search\&d=AJHR1864I.2.1.5.8\&srpos=25\&e=-------10--21---bySH---0-AJHR\%5f1864\%5fI\%5fAZz-G-.

${ }^{2}$ Coroner's inquest transcript, "Wreck of H.M.S. 'Orpheus," New Zealander, Volume XIX, Issue 1806, 28 February 1863, 7, https://paperspast.natlib.govt.nz/newspapers/new-zealander/1863/02/28/7.

${ }^{3}$ Quoted from the official verdict summary by Edward Hoskins, Officiating Judge Advocate of the court martial; cited in Thayer Fairburn, The Orpheus Disaster (Whakatane: Whakatane and District Historical Association, 1987), 146. In fact, the Orpheus ran aground on the Middle Bank, not the Bar itself.

${ }^{4}$ Land Information New Zealand, New Zealand Gazetteer, https://gazetteer.linz.govt.nz/place/679.

${ }^{5}$ The description of the Tasman's mood comes from a memoir by survivor James Mason, assistant boatswain on the Orpheus, in Roy M. Hetherington, The Wreck of H.M.S. Orpheus: New Zealand's Worst Sea Disaster (Melbourne: Cassell, 1975), 10. For the Orpheus as a "wet ship," see Fairburn, The Orpheus Disaster, 31.

${ }^{6}$ Royal Museums Greenwich, "Royal Navy Commodore's Frock Coat, 1864," object ID UNI0395, collections.rmg.co.uk/collections/objects/71609.html.

${ }^{7}$ Amanda Foreman, A World on Fire: Britain's Crucial Role in the American Civil War (New York: Random House, 2010), 404-17.

${ }^{8}$ Foreman, A World on Fire, 172-85.

${ }^{9}$ Fairburn, The Orpheus Disaster, 44-45.
} 
${ }^{10}$ Foreman, A World on Fire, 196-98.

${ }^{11}$ Fairburn, The Orpheus Disaster, 50-59.

${ }^{12}$ Foreman, A World on Fire, 410.

${ }^{13}$ Sir George Grey, letter to Captain Jenkins, senior naval officer in New Zealand (30 December 1862), in Fairburn, The Orpheus Disaster, 16-17.

${ }^{14}$ James Belich, The New Zealand Wars and the Victorian Interpretation of Racial Conflict (Auckland: Auckland University Press, 2015), 119-25.

${ }^{15}$ Alfred Domett, "Memorandum for His Excellency, The Governor," 27 January 1863, in Fairburn, The Orpheus Disaster, 17.

${ }^{16}$ Fairburn, The Orpheus Disaster, 6, 14, 65.

${ }^{17}$ Details of the decision-making aboard Orpheus are from the 1871 version of events by survivor Jimmy Davis, as recorded in J. G. Garland, "Narrative" (unpublished manuscript), cited in Fairburn, The Orpheus Disaster, 63.

${ }^{18}$ Charles Beale, H.M.S. Orpheus in Sydney Harbour 1862, photograph, fig. 72 in Fairburn, The Orpheus Disaster, 233.

19 . Fairburn, The Orpheus Disaster, 25--39.

${ }^{20}$ J. H. M. Abbott, "The Wreck of the Orpheus," Bathurst Advocate, 24 October 1913, in Fairburn, The Orpheus Disaster, 182.

${ }^{21}$ Fairburn, The Orpheus Disaster, 39.

${ }^{22}$ John Keats, "Robin Hood: To a Friend" (1818), www.poetryfoundation.org/poems/44483/robinhood.

${ }^{23}$ Ovid, Metamorphoses, trans. Sir Samuel Garth, John Dryden, et al., Internet Classics Archive, classics.mit.edu/Ovid/metam.html.

${ }^{24}$ A. W. Reed, Place Names of New Zealand, revised by Peter Dowling (Auckland: Raupo, 2010), 236.

${ }^{25}$ Reed, Place Names, 237.

${ }^{26}$ A.W. Reed and Garry G. Hooker, Supplement to Place Names of New Zealand (Wellington: Alfred and Isabel and Marian Reed Trust, 1979), 80.

${ }^{27}$ Reed, Place Names, 236.

${ }^{28}$ Maui Pomare and James Cowan, Legends of the Maori, Volume 1 (Wellington, Harry H. Tombs, 1930), 119. Pomare and Cowan translate the quoted text as "When you pass out beyond the Manuka waters, do not look back until you reach — or pass - the "Fishing-net of Tara."'

${ }^{29}$ Edward Wing, written account provided to Roy Hetherington, in Hetherington, The Wreck of H.M.S. Orpheus, 2.

${ }^{30}$ Iain Anderson, "Manukau Harbour," New Zealand Geographic 81 (September-October 2006): www.nzgeo.com/stories/manukau-harbour.

${ }^{31}$ This section is based on the testimony of Frederick Butler, from the Coroner's inquest transcript.

${ }^{32}$ This section is based on Wing's account, in Hetherington, The Wreck of H.M.S. Orpheus, 2-5.

${ }^{33}$ This section is based on the minutes of the court martial, reproduced in Fairburn, The Orpheus Disaster, 131-39.

${ }^{34}$ Fairburn, The Orpheus Disaster, 85-87.

${ }^{35}$ Fairburn, The Orpheus Disaster, 88-89.

${ }^{36}$ Fairburn, The Orpheus Disaster, 139-40.

${ }^{37}$ Mason, in Hetherington, The Wreck of H.M.S. Orpheus, 16-17.

${ }^{38}$ Lieutenant C. G. Brooke-Hunt ("midshipman Hunt" in 1863), "A Relic of Her Majesty's Ship Orpheus," letter to the Times, extracted in the New Zealand Herald, 3 July 1880, 6,

https://paperspast.natlib.govt.nz/newspapers/NZH18800703.2.42. The story of the Orpheus crew and officers going to their deaths with songs and "three British cheers" became legendary following initial reports, and provided the emotional focus for several valedictory poems and a memorial plaque in Hobart, all reproduced in Fairburn, The Orpheus Disaster, 236-37.

${ }^{39}$ Thomas Wing, letter to the editor, New Zealand Herald, 10 July 1880, 6, https://paperspast.natlib.govt.nz/newspapers/NZH18800710.2.51. 
${ }^{40}$ The approach described here draws on theories of "new materialism": see for example Bruno Latour's We Have Never Been Modern, trans. Catherine Porter (Cambridge, Mass.: Harvard University Press, 1993); or Jane Bennett's Vibrant Matter: A Political Ecology of Things (Durham and London: Duke University Press, 2010). Bennett, for instance, asks how differently we might see and treat the world if we were systematically to replace our view of "matter as passive stuff, as raw, brute or inert" with a notion of "vibrant matter" or "vital materiality." By these phrases Bennett means "the capacity of things - edibles, commodities, storms, metals — not only to impede or block the designs of humans but also to act as quasi agents or forces with trajectories, propensities or tendencies of their own" (viii).

${ }^{41}$ G. B. Richardson, The Universal Code of Signals for the Mercantile Marine of all Nations, by the Late Captain Marryat, R.N. (London: Richardson Brothers, 1858), 270, https://archive.org/details/TheUniversalCodeOfSignals/page/n269/mode/2up.

${ }^{42}$ Edward Wing, letter to the Bathurst Advocate (November 7, 1913), cited in Fairburn, The Orpheus Disaster, 184.

${ }^{43}$ Cited in Fairburn, The Orpheus Disaster, 146.

${ }^{44}$ Fairburn, The Orpheus Disaster, 155.

${ }^{45}$ Anderson, "Manukau Harbour."

${ }^{46}$ Hetherington, The Wreck of H.M.S. Orpheus, 82-83.

${ }^{47}$ Hetherington, The Wreck of H.M.S. Orpheus, 82-83.

${ }^{48}$ Fairburn, The Orpheus Disaster, 89.

${ }^{49}$ Commander J. W. Sullivan, letter to Captain Robert Jenkins of the Miranda (27 February 1863), in Fairburn, The Orpheus Disaster, 97-98.

${ }^{50}$ Fairburn, The Orpheus Disaster, 170-73.

${ }^{51}$ Hetherington, The Wreck of H.M.S. Orpheus, 84-85.

${ }^{52}$ Fairburn, The Orpheus Disaster, 21-23.

${ }^{53}$ Trans-Tasman Resources Ltd, "Offshore Iron Ore Extraction,” www.ttrl.co.nz. 